\title{
Activity of acetylcholinesterase (AChE) in male albino rats exposed to metal welding fumes in an experimental setting
}

\author{
Ali Sani ${ }^{12^{2}}{ }^{\circledR}$, Ibrahim Lawal Abdullahi ${ }^{1}{ }^{\complement}$, Sani Ibrahim ${ }^{1}$ \\ ${ }^{1}$ Department of Biological Sciences, Bayero University Kano, P.M.B. 3011, Kano, Nigeria \\ ${ }^{2}$ Department of Instrument Science and Engineering, School of Electronic, Information and Electrical Engineering, Shanghai Jiao Tong \\ University, 200240, Shanghai, China
}

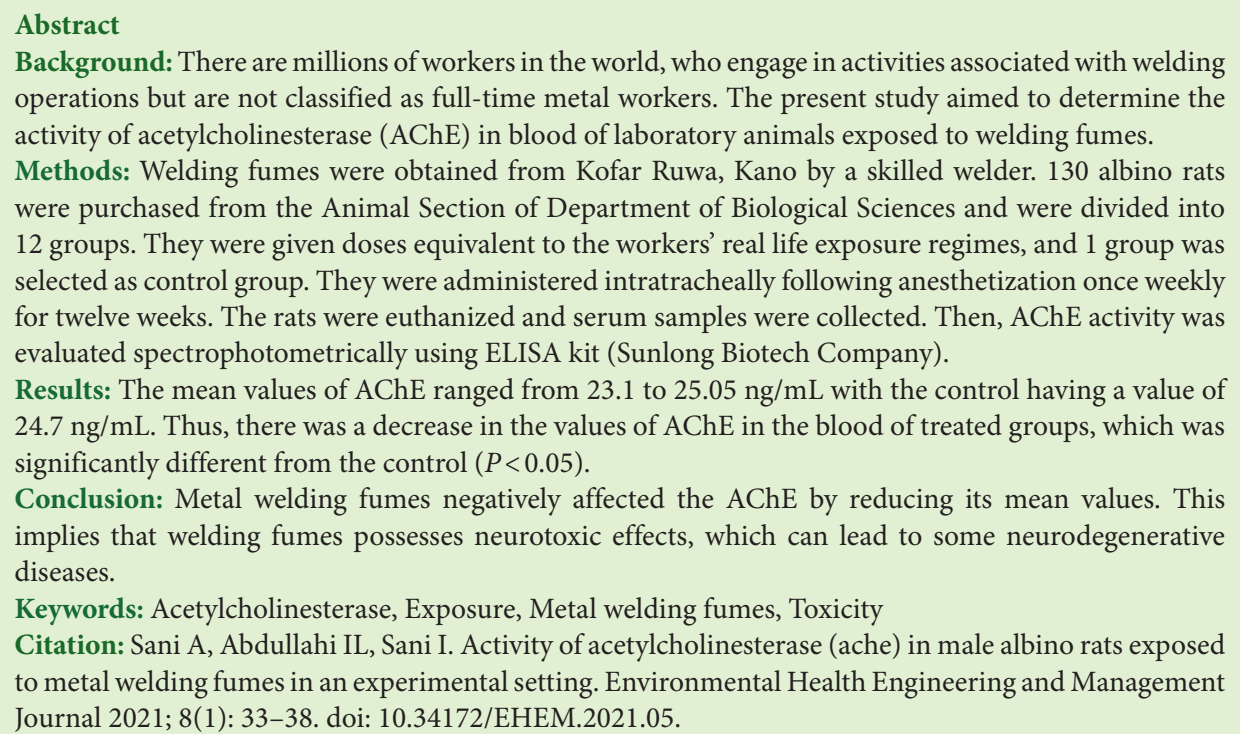

\section{Introduction}

All around the world, there are many workers who are not regarded as full-time welders though they engage in activities related to welding. Around 800000 workers are regarded as full-time welders globally, and approximately 410040 workers are regarded as welders, cutters, solderers, and brazers in the United States alone (1). The process of welding involves the vaporization of the metals and oxides of an electrode or wire that is consumed during the process to release fumes/dusts. Particulates are generated from excessive condensation of the vapours which are comprised of different metal oxides that are related to the electrode composition (2). The process by which hightemperature metal vapours are transformed into primary particles is called nucleation (3). Metal works are found all over the states landscape and regarded among the major economic activities in the area. Many individuals are involved in the occupation without knowing the hazards and risks associated with it. In addition, there is less or no regulation and control to checkmate the proper conduction of the activities in order to safeguard the health of the people and environment at large. So far, the toxicity and associated implications that result from metal fumes and particles exposure are largely unattended. There is also no information about the severity length of the problem in the urban population of Kano, Nigeria, while it can broaden the scope of environmental health issues in urban population of Kano, Nigeria. Therefore, the present study aimed to determine the activity of acetylcholinesterase (AChE) in blood of laboratory animals exposed to welding fumes.

\section{Materials and Methods}

\section{Collection of welding fumes}

Open front cubicle that resembles a chamber was used to collect the produced fumes. The volume of the chamber is $1 \mathrm{~m}^{3}$. A skilful metal worker performed the manual metal welding (shielded manual metal arc welding) process using a stainless steel hard surfacing electrode (Hyundai Welding electrode low hydrogen E $70183.2 \mathrm{~mm}$ ) and the 
fumes were dusted on a $0.2-\mu \mathrm{m}$ nuclepore filters. A large amount of fumes were collected just before the start of the study. Furthermore, the obtained fumes were suspended subsequently in distilled water and sonicated for 1 minutes (4).

\section{Experimental design}

In this study, 130 male Albino rats (Rattus norvegicus) with a weight between 210 to $250 \mathrm{~g}$ were collected from the Animal Section, Department of Biological Sciences, Bayero University, Kano, and divided into 13 experimental groups ( $n=10$ per group) (5). The animals were kept at an animal house in Aminu Kano Teaching Hospital located in Kano, Nigeria. The experimental design used for this study was randomized block design. The animals were acclimatized for 14 days prior to treatment.

Housing and feeding conditions for experimental animals

The animal house had restricted access and was free of pathogens and other extraneous factors. The animals were put in cages and a mark was made on their tails for identification.

The room temperature and relative humidity were about $22^{\circ} \mathrm{C}\left( \pm 3^{\circ} \mathrm{C}\right)$ and $30 \%$, respectively. Also, the light-dark cycle of 12 hours was used in this study. The rats were fed with a conventional laboratory diet and water ad libitum. Ethical clearance for the study was obtained from College of Health Sciences Research Ethics Committee (CHSREC), Bayero University, Kano, Nigeria (6).

\section{Preparation of the test substance}

The dose administered in this study followed a real-time workers exposure schedule, which was adopted from the study of Sani and Abdullahi (5). It was presented as follows:

A simulation was used to evaluate the lung burden of metal workers with various working regimes (hours/day) $(7,8)$. The factors that were considered for the simulation include:

Fume concentration $\left(5 \mathrm{mg} \mathrm{m}^{-3}\right.$, threshold limit value for welding fumes), human minute ventilation volume (20000 $\mathrm{mL} \mathrm{min}^{-1} \times 10^{-6} \mathrm{~m}^{3} \mathrm{~mL}^{-1}$ ), daily duration of exposure (no. of $\mathrm{h} /$ day $\times 60 \mathrm{~min} \mathrm{~h}^{-1}$ ), and efficiency of deposition (15\%) $(9,10)$.

With regard to the above-mentioned elements, the daily burden of metal workers for several hours per day was obtained by the following calculations:

1. Metal worker daily burden $(2 \mathrm{~h} /$ day $)=$ fume concentration $\left(5 \mathrm{mg} / \mathrm{m}^{3}\right) \times$ human minute ventilation volume $\left(20000 \mathrm{~mL} / \mathrm{min} \times 10^{-6} \mathrm{~m}^{3} / \mathrm{mL}\right) \times$ exposure duration $(2 \mathrm{~h} /$ day $\times 60 \mathrm{~min} / \mathrm{hr}) \times$ deposition efficiency $(15 \%)=1.8 \mathrm{mg}$

The surface area of alveolar epithelium ( $\mathrm{rat}=0.4 \mathrm{~m}^{2}$; human $=102 \mathrm{~m}^{2}$ ) was used as dose metric (11). Rat daily burden of exposure was obtained to be $0.0070 \mathrm{mg}$. Then, similar exposure in rats for $3,5,10$, and 20 years were obtained to be $7.66,12.77,25.55$, and $51.10 \mathrm{mg}$, respectively, considering 365 days as a year. The concentrations were administered over 12 weeks.

2. Metal worker daily burden $(4 \mathrm{~h} /$ day $)=$ fume concentration $\left(5 \mathrm{mg} / \mathrm{m}^{3}\right) \times$ human minute ventilation volume $\left(20000 \mathrm{~mL} / \mathrm{min} \times 10-6 \mathrm{~m}^{3} / \mathrm{mL}\right) \times$ exposure duration $(4 \mathrm{~h} /$ day $\times 60 \mathrm{~min} / \mathrm{h}) \times$ deposition efficiency $(15 \%)=3.6 \mathrm{mg}$

The surface area of alveolar epithelium (rat $=0.4 \mathrm{~m}^{2}$; human $=102 \mathrm{~m}^{2}$ ) was used as a dose metric (11). The daily burden for rat exposure was obtained to be 0.0141 $\mathrm{mg}$. Then, such exposure regimes in rats for $3,5,10$, and 20 years were obtained to be $15.44,25.73,51.46$, and 102.93 $\mathrm{mg}$, respectively, considering 365 days as a year. The concentrations were administered over 12 weeks.

3. Metal worker daily burden $(8 \mathrm{~h} /$ day $)=$ fume concentration $\left(5 \mathrm{mg} / \mathrm{m}^{3}\right) \times$ human minute ventilation volume $\left(20000 \mathrm{~mL} / \mathrm{min} \times 10-6 \mathrm{~m}^{3} / \mathrm{mL}\right) \times$ exposure duration $(8 \mathrm{~h} /$ day $\times 60 \mathrm{~min} / \mathrm{h}) \times$ deposition efficiency $(15 \%)=7.2 \mathrm{mg}$

The surface area of alveolar epithelium (rat $=0.4 \mathrm{~m}^{2}$; human $=102 \mathrm{~m}^{2}$ ) was used as dose metric (11). The daily burden for rat exposure was obtained to be $0.0282 \mathrm{mg}$. Then, such exposure regimes in the rats for $3,5,10$, and 20 years were obtained to be $30.88,51.46,102.93$, and $205.86 \mathrm{mg}$, respectively, considering 365 days as a year. The concentrations were administered over 12 weeks.

Table 1 shows the working concentrations of metal welding fumes administered to the albino rats over a period of 12 weeks. Each concentration was administered per animal per week (5).

The samples of the metal fumes were prepared in sterile saline, and then, were sonicated for 1 minutes to have equal distribution of the fumes throughout the solution. The samples were prepared weekly prior to administration. Rats were anaesthetized with ketamine $(0.1 \mathrm{~mL} / 100 \mathrm{~g}$ b.w I.P), and following the loss of consciousness, the animals were intratracheally instilled with the respective dose per animal once a week for 12 weeks. Control groups received $200 \mu \mathrm{L}$ sterile saline via intratracheal route after anaesthesia (12).

\section{Collection of blood samples}

The experimental animals were euthanized a week after the last 12th week of administration. Blood samples were collected from the jugular vein into a plain bottle and taken to the laboratory. However, the blood samples were centrifuged to obtain the serum for the analysis $(12,13)$.

Table 1. Working values for test substances administered to the animal groups used in the present study

\begin{tabular}{lll}
\hline & \multicolumn{3}{c}{ Groups } \\
\hline Group IA: $0.64 \mathrm{mg}$ & Group IIA: $1.29 \mathrm{mg}$ & Group IIIA: $2.57 \mathrm{mg}$ \\
\hline Group IB: $1.06 \mathrm{mg}$ & Group IIB: $2.14 \mathrm{mg}$ & Group IIIB: $4.27 \mathrm{mg}$ \\
\hline Group IC: $2.13 \mathrm{mg}$ & Group IIC: $4.29 \mathrm{mg}$ & Group IIIC: $8.56 \mathrm{mg}$ \\
\hline Group ID: $4.26 \mathrm{mg}$ & Group IID: $8.58 \mathrm{mg}$ & Group IIID: $17.16 \mathrm{mg}$ \\
\hline
\end{tabular}




\section{Determination of acetylcholinesterase activity}

The activity of AChE was determined spectrophotometrically using ELISA kit (Sunlong Biotech Company).

\section{Statistical analysis}

Relevant statistical tools were employed to analyze data or results obtained from the study. Means of various parameters were analyzed statistically to check for statistical differences by ANOVA using SigmaStat version 3.5. Confidence interval was taken at $95 \%$ and statistical significant level was considered at $P<0.05$.

\section{Results}

The mean values ranged from 23.1 to $25.05 \mathrm{ng} / \mathrm{mL}$ with the control having a value of $24.7 \mathrm{ng} / \mathrm{mL}$. The values of AChE decreased across the groups IA, IB, IC, and ID, which was statistically significant $(P<0.05)$ (Table 2$)$. Similarly, the values of AChE decreased across the groups IIA, IIB, IIC, and IID, which was statistically significant $(P<0.05)$ (Table 2). All the values are less than the control value of $24.7 \mathrm{ng} / \mathrm{mL}$. In addition, the values of AChE decreased across the groups IIIA, IIIB, IIIC, and IIID, which was statistically significant $(P<0.05)$. All the values are less than the control value of $24.7 \mathrm{ng} / \mathrm{mL}$ as presented in Table 2.

\section{Discussion}

$\mathrm{AChE}$ is an important enzyme in the central nervous system that helps promote the transmission and catalysis of acetylcholine, which is a neurotransmitter in cholinergic synapses. It is related to the regulation of outgrowth and survival of neurons and intracellular calcium levels (14). Therefore, AChE inhibitors are crucial in the management of neurodegenerative disorders such as Alzheimer's disease (15). The activity of AChE is mostly evaluated in the prediction of neurotoxicity induction as is the case with high manganese $(\mathrm{Mn})$ exposure. Acetylcholine is transported to the nerve ends via axonal transport and released into the synaptic space (16).

The suppression of AChE leads to the accumulation of AChE in the synapses of nerve muscles and creates abnormal results, most importantly, higher activity of muscle tissues (17).

Table 2. Mean values of $A C h E(n g / m L)$ in blood of experimental rats exposed to metal fumes

\begin{tabular}{lccc}
\hline Test animal groups & I & II & III \\
\hline A & 25.05 & 24.03 & 23.63 \\
\hline B & 24.58 & 23.91 & 23.40 \\
\hline C & 24.45 & 23.57 & 23.10 \\
\hline D & 23.63 & 23.075 & 21.90 \\
\hline Control & 24.25 & 24.25 & 24.25 \\
\hline$P$ value & $<0.05$ & $<0.05$ & $<0.05$
\end{tabular}

One of the metals present in the welding fumes is Mn. It acts as an antioxidative enzyme cofactor of Mn superoxide dismutase or AChE that functions in the production and transfer of neurotransmitters $(18,19)$.

In addition, many studies have reported a modification in AChE activity resulting from $\mathrm{Mn}$ substitution and increased accumulation of AChE in the brain. Thus, it causes a reduction in the control of muscle and nerve. In addition, neurotoxin effects which seems to be under the effect of pollutants are related to changes in normal behaviours (20). The accumulation of metals taken that enter the body through different routes at various levels in organs and tissues was reported. Those metals that possess some physiologic functions are stored and could be thrown out after joining in some metabolic ways in the living body. Toxic stored metals could damage enzyme structure (21).

Lead $(\mathrm{Pb})$ and zinc $(\mathrm{Zn})$ were revealed to inhibit $\mathrm{AChE}$ activity in the brain tissue of zebrafish (Danio rerio) (22). As reported in the present study, the levels of AChE decreased by exposure to metal fumes. The inhibition under the effect of $\mathrm{Pb}$ could be caused by binding the metal to the functional groups of proteins like imidazole, sulfhydryl, and carboxyl (23). There was emergence of catalytic activity loss in functional groups (24). It showed a significant inhibition of AChE in the brain and muscle tissues following sublethal administration of cadmium (Cd) to zebrafish (25). The same result was obtained on Mugil cephalus and zebrafish after exposure to $\mathrm{Cd}$, Iron $(\mathrm{Fe})$, copper $(\mathrm{Cu}), \mathrm{Pb}$, and $\mathrm{Zn}(26)$, which is consistent with the results of the present study. Mercury $(\mathrm{Hg}), \mathrm{Cd}$, $\mathrm{Pb}$, and arsenic (As) are among the toxic heavy metals whose accumulation could lead to disorders of central nervous system, low energy generation, and damage to the composition of most important organs (27). Excessive exposure to pollutants could lead to slow and progressive physical and mental problems such as neurodegenerative process of Alzheimer's disease and Parkinson's disease (28).

Such heavy metals and organophosphates are renowned inhibitors of AChE which can alter its efficiency $(22,29)$. This has been supported by the findings of the present study where exposure to the welding metal fumes inhibits AChE by reducing its levels as seen in Table 2 .

There is an interaction between heavy metals including $\mathrm{Hg} / \mathrm{Pb}$ and the causes of neurodegenerative diseases. Such metals could accumulate in the brain which by crossing blood-brain barrier can induce oxidative stress and may lead to neurodegenerative diseases such as Alzheimer's disease and Parkinson's disease (27). Hence, cholinergic system is responsible for manifestations of behaviour in animals (30). It has been reported that $\mathrm{Pb}$ has caused impairments of AChE system, and subsequently, cognitive problems in animals exposed to $\mathrm{Pb}$. The inhibition of $\mathrm{AChE}$ is one of the early biomarkers of exposure to environmental toxins in humans and is associated with 
adverse health effects on the nervous system after exposure to metals and insecticides such as organophosphate (31). The basic concept of monitoring and applying inhibition of $\mathrm{AChE}$ and its subsequent monitoring is applied and used as a biological marker for assessing and real-time detection of exposure to hazardous compounds in the occupational setting and environmental medicine (32). Exposure to $\mathrm{Pb}$ obviously reduces the red blood cells (RBCs) and activity of AChE in plasma and has a negative association with blood $\mathrm{Pb}$ concentration. The reduction in $\mathrm{RBC}$ and plasma $\mathrm{AChE}$, as reported by the present study, shows damages to the cholinergic activity, which leads to neurotoxicity in the $\mathrm{Pb}$-exposed workers (33). Many studies have reported that AChE activity is decreased following the exposure to free radicals and inhibitory effect of $\mathrm{Pb}$ on $\mathrm{AChE}(33,34)$. The mechanism is that $\mathrm{Pb}$ shows stronger affinity for free-SH groups in enzymes and proteins whose binding could affect their function, resulting in cholinergic receptors desensitization and effectiveness in the action of transmission (35). According to a study by Reddy et al, the change in the activity of Ach and $\mathrm{AChE}$ can progress after withdrawal of $\mathrm{Pb}$ exposure (36). Probably as a result of inhibition of AChE activity by $\mathrm{Pb}$ in synaptosomal cortex, hippocampus, and cerebellum regions of the brain. However, their susceptibility to $\mathrm{Pb}$ exposure depends on the maturation and formation of differences (37). Exposure to $\mathrm{Pb}$ at physiologically relevant concentrations causes relative inhibition of AChE activity in the midbrain, and subsequently, defects of neurobehaviour and disruption of $\mathrm{AChE}$ at specific region and acetylcholine receptors (38).

$\mathrm{Hg}, \mathrm{Cd}$, and $\mathrm{Pb}$ have been observed to disrupt the activity of AChE in the central nervous system of the red swamp cray fish after exposure to sub-lethal concentrations of the metals affected (39). Therefore, it can be suggested that oxidative damage in the zebrafish brain has resulted in a significant reduction in AChE activity but has not affected the pattern of gene expression. High concentrations of $\mathrm{Hg}$ can directly inhibit AChE activity in vitro experiments whereas lower doses of this metal cannot alter the enzyme activity (22). After a short-term exposure to Cd, AChE activity in the brain of adult rats has been inhibited with additional induced oxidative stress (39).

Metals, carbamates, and organophosphates have revealed inhibition of AChE. However, some studies have recently suggested that some metals can activate AChE during acute exposure (40). Hypothetically, it has been demonstrated that metals could interact with AChE receptors during acute exposure by influencing their binding capacity, which ultimately, leads to increased AChE (40). Similarly, initial increase after exposure was observed in groups exposed to lower doses of metal welding fumes in the present study. It has been reported that metals, carbamates, and organophosphates inhibit AChE (41,42).

Though there are reports that described inhibition of AChE by metals under acute exposure, some suggest otherwise. Zatta et al have revealed an elevation of AChE in rats administered $\mathrm{Al}$ orally (43). Some studies have explained the effect of stimulation by $\mathrm{Pb}$ in rats and oligochaetes $(42,44)$. Also, Gallegos et al have described that $\mathrm{Hg}(0.4 \mathrm{mg} / \mathrm{L})$ leads to a significant increase in the activity of esterase in Callianas sathyrrena (45). The increased activity of AChE might also be associated with an up-regulation of AChE gene, due to an initial inhibitory effect of metals (40). Gallegos et al have reported an increase in the activity of AChE in rat's brain that were exposed to $10 \mathrm{mg} / \mathrm{kg} \mathrm{Pb}$, after 30 minutes, though there was a sharp reduction in this activity after 24 and 72 exposure hours (45). Hence, the initial increase in the activity of AChE after exposure to metals might be a feedback to acute toxicity. However, a reduction would be expected after excessive exposure periods. Perhaps after chronic exposure, metals would be able to inhibit AChE, as proposed and observed in the present study.

\section{Conclusion}

According to the results, the metal welding fumes negatively affected the AChE by reducing its values in blood of treated groups, which was significantly different from the control group $(P<0.05)$. This implies that welding fumes have neurotoxic effects which can lead to some neurodegenerative diseases.

\section{Acknowledgements}

The authors would like to express their gratitude to the staff of Department of Biological Sciences, Bayero University, Kano, for supporting this study.

\section{Ethical issues}

The authors certify that the data collected during the study are as stated in the manuscript, and no data from the study has been or will be published separately elsewhere.

\section{Competing interests}

The authors declare that they have no conflict of interests.

\section{Authors' contributions}

All authors contributed and involved actively in the problem analysis, experiments design and execution, data collection and analysis, manuscript preparation and approval.

\section{References}

1. U.S. Bureau of Labor Statistics. Occupational Employment Statistics. USA: Bureau of Labor Statistics; 2020.

2. Harris MK. Welding Health and Safety: A Field Guide for OEHS Professionals. USA: American Industrial Hygiene Association; 2002. p. 214.

3. Zimmer AT. The influence of metallurgy on the formation of welding aerosols. J Environ Monit 2002; 4(5): 628-32. doi: $10.1039 / \mathrm{b} 202337 \mathrm{~g}$. 
4. Popstojanov R, Antonini JM, Salmen R, Ye M, Zheng W, Castranova V, et al. Alterations in cardiomyocyte function after pulmonary treatment with stainless steel welding fume in rats. J Toxicol Environ Health A 2014; 77(12): 70515. doi: 10.1080/15287394.2014.888692.

5. Sani A, Abdullahi IL. Effects of welding fumes on haematological parameters of male albino rats (Rattusnorvegicus). Biochemistry and Biophysics Reports 2019; 19: 100651. doi: 10.1016/j.bbrep.2019.100651.

6. OECD, OCDE. Guideline for the Testing of Chemicals. France: OECD; 2018.

7. Antonini JM, Roberts JR, Chapman RS, Soukup JM, Ghio AJ, Sriram K. Pulmonary toxicity and extrapulmonary tissue distribution of metals after repeated exposure to different welding fumes. Inhal Toxicol 2010; 22(10): 80516. doi: 10.3109/08958371003621641.

8. Sriram K, Lin GX, Jefferson AM, Roberts JR, Wirth O, Hayashi Y, et al. Mitochondrial dysfunction and loss of Parkinson's disease-linked proteins contribute to neurotoxicity of manganese-containing welding fumes. FASEB J 2010; 24(12): 4989-5002. doi: 10.1096/fj.10163964.

9. Human respiratory tract model for radiological protection. A report of a Task Group of the International Commission on Radiological Protection. Ann ICRP 1994; 24(1-3): 1-482.

10. Antonini JM, Afshari AA, Stone S, Chen B, SchweglerBerry D, Fletcher WG, et al. Design, construction, and characterization of a novel robotic welding fume generator and inhalation exposure system for laboratory animals. J Occup Environ Hyg 2006; 3(4): 194-203. doi: $10.1080 / 15459620600584352$.

11. Stone KC, Mercer RR, Gehr P, Stockstill B, Crapo JD. Allometric relationships of cell numbers and size in the mammalian lung. Am J Respir Cell Mol Biol 1992; 6(2): 235-43. doi: 10.1165/ajrcmb/6.2.235.

12. Antonini JM, Roberts JR, Schwegler-Berry D, Mercer RR. Comparative microscopic study of human and rat lungs after overexposure to welding fume. Ann Occup Hyg 2013; 57(9): 1167-79. doi: 10.1093/annhyg/met032.

13. Hoff J, Rlagt LV. Methods of blood collection in the mouse. Lab Animal 2000; 29(10): 47-53.

14. Ong WY, Farooqui AA. Iron, neuroinflammation, and Alzheimer's disease. J Alzheimers Dis 2005; 8(2): 183-200. doi: 10.3233/jad-2005-8211.

15. Quintana C, Bellefqih S, Laval JY, Guerquin-Kern JL, Wu TD, Avila J, et al. Study of the localization of iron, ferritin, and hemosiderin in Alzheimer's disease hippocampus by analytical microscopy at the subcellular level. J Struct Biol 2006; 153(1): 42-54. doi: 10.1016/j.jsb.2005.11.001.

16. Geula C, Nagykery N, Nicholas A, Wu CK. Cholinergic neuronal and axonal abnormalities are present early in aging and in Alzheimer disease. J Neuropathol Exp Neurol 2008; 67(4): 309-18. doi: 10.1097/NEN.0b013e31816a1df3.

17. Roex EW, Keijzers R, van Gestel CA. Acetylcholinesterase inhibition and increased food consumption rate in the zebrafish, Danio rerio, after chronic exposure to parathion. Aquat Toxicol 2003; 64(4): 451-60. doi: 10.1016/s0166445x(03)00100-0.

18. Aschner M, Guilarte TR, Schneider JS, Zheng W. Manganese: Recent advances in understanding its transport and neurotoxicity. Toxicol Appl Pharmacol 2007; 221(2): 131-47. doi: 10.1016/j.taap.2007.03.001.

19. Sidoryk-Wegrzynowicz M, Aschner M. Manganese toxicity in the central nervous system: the glutamine/glutamate- $\gamma$ aminobutyric acid cycle. J Intern Med 2013; 273(5): 466-77. doi: 10.1111/joim.12040.

20. Pereira VM, Bortolotto JW, Kist LW, Azevedo MB, Fritsch RS, Oliveira Rda L, et al. Endosulfan exposure inhibits brain AChE activity and impairs swimming performance in adult zebrafish (Danio rerio). Neurotoxicology 2012; 33(3): 469-75. doi: 10.1016/j.neuro.2012.03.005.

21. Yazkan $\mathrm{M}$, Özdemir F, Gölükçü $\mathrm{M}$. $\mathrm{Cu}, \mathrm{Zn}, \mathrm{Pb}$ and $\mathrm{Cd}$ contents in some molluscs and crustacean in the Gulf of Antalya. Turkish Journal of Veterinary and Animal Sciences 2004; 28: 95-100.

22. Richetti SK, Rosemberg DB, Ventura-Lima J, Monserrat JM, Bogo MR, Bonan CD. Acetylcholinesterase activity and antioxidant capacity of zebrafish brain is altered by heavy metal exposure. Neurotoxicology 2011; 32(1): 116-22. doi: 10.1016/j.neuro.2010.11.001.

23. Najimi S, Bouhaimi A, Daubèze M, Zekhnini A, Pellerin J, Narbonne JF, et al. Use of acetylcholinesterase in Pernaperna and Mytilusgalloprovincialis as a biomarker of pollution in Agadir Marine Bay (South of Morocco). Bull Environ Contam Toxicol 1997; 58(6): 901-8. doi: 10.1007/ s001289900419.

24. Sant'Anna MC, Soares Vde M, Seibt KJ, Ghisleni G, Rico EP, Rosemberg DB, et al. Iron exposure modifies acetylcholinesterase activity inzebrafish (Daniorerio) tissues: distinct susceptibility of tissues to iron overload. Fish Physiol Biochem 37(3): 573-81. doi: 10.1007/s10695010-9459-7.

25. Al-Sawafi AG, Yan Y. Alterations of acetylcholinesterase activity and antioxidant capacity of zebrafish brain and muscle exposed to sublethal level of cadmium. International Journal of Environmental Science and Development 2013; 4(3): 221-230. doi: 10.18178/IJESD.

26. Rajkumar JS, Milton J. Biochemical markers of oxidative stress in mugilcephalus exposed to cadmium, copper, lead and zinc. International Journal of Pharma and Bio Sciences 2011; 2(3): 41-50.

27. Monnet-Tschudi F, Zurich MG, Boschat C, Corbaz A, Honegger P. Involvement of environmental mercury and lead in the etiology of neurodegenerative diseases. Rev Environ Health 2006; 21(2): 105-17. doi: 10.1515/ reveh.2006.21.2.105.

28. Migliore L, Coppedè F. Environmental-induced oxidative stress in neurodegenerative disorders and aging. Mutat Res 2009; 674(1-2): 73-84. doi: 10.1016/j.mrgentox.2008.09.013.

29. Frasco MF, Fournier D, Carvalho F, Guilhermino L. Do metals inhibit acetylcholinesterase (AChE)? Implementation of assay conditions for the use of $\mathrm{AChE}$ activity as a biomarker of metal toxicity. Biomarkers 2005; 10(5): 360-75. doi: 10.1080/13547500500264660.

30. Reddy GR, Devi BC, Chetty CS. Developmental lead neurotoxicity: alterations in brain cholinergic system. Neurotoxicology 2007; 28(2): 402-7. doi: 10.1016/j. neuro.2006.03.018.

31. Lionetto MG, Caricato R, Calisi A, Giordano ME, Schettino T. Acetylcholinesterase as a biomarker in environmental 
and occupational medicine: New insights and future perspectives. Biomed Res Int 2013; 2013: 321213. doi: $10.1155 / 2013 / 321213$.

32. Knudsen LE, Hansen AM. Biomarkers of intermediate endpoints in environmental and occupational health. Int J Hyg Environ Health 2007; 210(3-4): 461-70. doi: 10.1016/j. ijheh.2007.01.015.

33. Khan MI, Mahdi AA, Islam N, Rastogi SK, Negi MP. Assessment of erythrocyte acetylcholine esterase activities in painters. Indian J Occup Environ Med 2009; 13(1): 23-7. doi: 10.4103/0019-5278.50720.

34. Tsakiris S, Angelogianni P, Schulpis KH, Stavridis JC. Protective effect of L-phenylalanine on rat brain acetylcholinesterase inhibition induced by free radicals. Clin Biochem 2000; 33(2): 103-6. doi: 10.1016/s00099120(99)00090-9.

35. Chetty CS, Rajanna S, Hall E, Yallapragada PR, Rajanna B. In vitro and in vivo effects of lead, methyl mercury and mercury on inositol 1,4,5-trisphosphate and 1,3,4,5-tetrakisphosphate receptor bindings in rat brain. Toxicol Lett 1996; 87(1): 11-7. doi: 10.1016/03784274(96)03670-3.

36. Reddy GR, Basha MR, Devi CB, Suresh A, Baker JL, Shafeek $A$, et al. Lead induced effects on acetylcholinesterase activity in cerebellum and hippocampus of developing rat. Int J Dev Neurosci 2003; 21(6): 347-52. doi: 10.1016/s07365748(03)00071-6.

37. Abou-Donia MB, Dechkovskaia AM, Goldstein LB, Abdel-Rahman A, Bullman SL, Khan WA. Co-exposure to pyridostigmine bromide, DEET, and/or permethrin causes sensorimotor deficit and alterations in brain acetylcholinesterase activity. Pharmacol Biochem Behav 2004; 77(2): 253-62. doi: 10.1016/j.pbb.2003.10.018.

38. Devi M, Fingerman M. Inhibition of acetylcholinesterase activity in the central nervous system of the red swamp crayfish, Procambarus clarkii, by mercury, cadmium, and lead. Bull Environ Contam Toxicol 1995; 55(5): 746-50. doi:
$10.1007 / \mathrm{BF} 00203762$.

39. Carageorgiou H, Tzotzes V, Pantos C, Mourouzis C, Zarros A, Tsakiris S. In vivo and in vitro effects of cadmium on adult rat brain total antioxidant status, acetylcholinesterase, $(\mathrm{Na}+, \mathrm{K}+)$-ATPase and $\mathrm{Mg} 2+-\mathrm{ATPase}$ activities: protection by L-cysteine. Basic Clin Pharmacol Toxicol 2004; 94(3): 112-8. doi: 10.1111/j.1742-7843.2004.pto940303.x.

40. Bainy AC, de Medeiros MH, Mascio PD, de Almeida EA. In vivo effects of metals on the acetylcholinesterase activityof the Perna perna mussel's digestive gland. Biotemas 2006; 19(1): 35-9.

41. Guilhermino L, Lacerda MN, Nogueira AJ, Soares AM. In vitro and in vivo inhibition of Daphnia magna acetylcholinesterase by surfactant agents: possible implications for contamination biomonitoring. Sci Total Environ 2000; 247(2-3): 137-41. doi: 10.1016/s00489697(99)00485-4.

42. Martinez-Tabche L, Ortega MD, Mora BR, Faz CG, Lopez EL, Martinez MG. Hemoglobin concentration and acetylcholinesterase activity of oligochaetes in relation to lead concentration in spiked sediments from Ignacio Ramirez reservoir. Ecotoxicology and Environmental Safety 2001; 49(1): 76-83. doi.org/10.1006/eesa.2001.2030.

43. Zatta P, Ibn-Lkhayat-Idrissi M, Zambenedetti P, Kilyen $\mathrm{M}$, Kiss T. In vivo and in vitro effects of aluminum on the activity of mouse brain acetylcholinesterase. Brain Res Bull 2002; 59(1): 41-5. doi: 10.1016/s0361-9230(02)00836-5.

44. Flora GJ, Seth PK. Alterations in some membrane properties in rat brain following exposure to lead. Cytobios 2000; 103(403): 103-9.

45. Hernández Gallegos ME, Ibarra Zannatha MM, García Osornio E, Sierra Sánchez A, Posadas del Rio FA. Immediate and delayed effects of lead on AChE, GSH-T and thiols in the substantia nigra, neostriatum and cortex of the rat brain. J Appl Toxicol 2001; 21(5): 397-401. doi: 10.1002/jat.766. 